\title{
Knowledge and Perceptions on Urban Health Hazards in Zambia: A Case Study of Kitwe District
}

\author{
Cecilia Muchepa Muzyamba \\ Zambian Open University, Lusaka, Zambia
}

\begin{abstract}
Knowledge and perceptions of urban health hazards may vary in different communities. An attempt was made to study the levels of knowledge and perceptions on urban health hazards in Zambia: a case study of Kitwe District. The study was done in Nkana West, Chimwemwe, and Saint Anthony (St. Anthony). The respondents in these areas identified the following factors as being hazardous: air pollution, promiscuous behavior, sanitation, poor houses, solid and faecal waste management, noise, lack of recreational facilities, inadequate food supplies, life styles, and overcrowdings. The study revealed that $98 \%$ of respondents knew at least a health hazard while $2 \%$ of them did not know of any. Of the $98 \%$, there were $39.6 \%$ responses indicated that air pollution was the most hazardous followed by unhygienic environments with $35.9 \%$. Promiscuous behavior, inadequate food supply, and garbage (solid waste) disposal with $32.1 \%, 30.2 \%$, and $28.3 \%$, respectively, were some of the most common. The responses given were related to the socio-economic status of the sample areas. The respondents were of the perception that the government was to blame over the rates of air pollution and sanitation. However, some respondents acknowledged the blame of disposing solid waste in undesignated areas. The promiscuous behavior was attributed to inadequate recreation facilities, unemployment, and a lot of beer outlets. There was therefore, need for government through the Ministry of Health (MOH) and the Kitwe City Council (KCC) to carry basic health campaigns on the environmental health hazards. The construction of houses should be monitored by the housing (buildings) department of the KCC in order to avoid people putting up buildings where the drainage canals are supposed to pass. This would help minimize water logging.
\end{abstract}

Keywords: hazard, health, knowledge, perceptions, urban

Urban health is threatened amidst a lot of activities as people try to fend for themselves. Health is cardinal in order for the country to develop its all spheres. Therefore, in 1994, the World Health Organization (WHO) came up with the campaign for the "health for all" (Government of the Republic of Zambia and United Nations Development Programme [GRZ \& UNDP], 2013). This was after realization that any country cannot prosper with a sickly population as financial capital would be diverted toward the procurement of drugs and provision of holistic health care delivery. The urban health hazards are not only a challenge to national development but also potential threats to human wellbeing.

Urban health hazards in Zambia are numerous and these need to be addressed if people's lives are to be safe guarded. Some of the health hazards the people of Zambia are faced with are: noise pollution, road

Corresponding author: Cecilia Muchepa Muzyamba, Ph.D. candidate and lecturer in geography, Zambian Open University, Lusaka, Zambia; research fields: spatial and temporal distribution of diseases (medical geography), geography of ageing and eco-tourism, and spatial development initiatives (SDIs). E-mail: ceciliamuchepa@yahoo.com. 
accidents, water pollution, overcrowding (in homes and communities), poor sanitation, lack or inadequate food supplies, air pollution, and urban life styles of the people. Urban life styles are perceived as health hazards due to their dietary patterns (Akhtar, 1988). Chanda (2004) states that in metallurgical and mine operations, there are variations in the concentration of sulphur gas emissions. These vary from mine to mine and time to time. However, whatever the quantity, they still have repurcations on the health of the people and also on the biodiversity. This means that the Copperbelt of Zambia is greatly affected since copper is the chief foreign exchange earner.

The study was done in Kitwe - the hub of the Copperbelt. The town is centrally located in the region and all routes from parts of the Copperbelt converge here (see Figure 1).

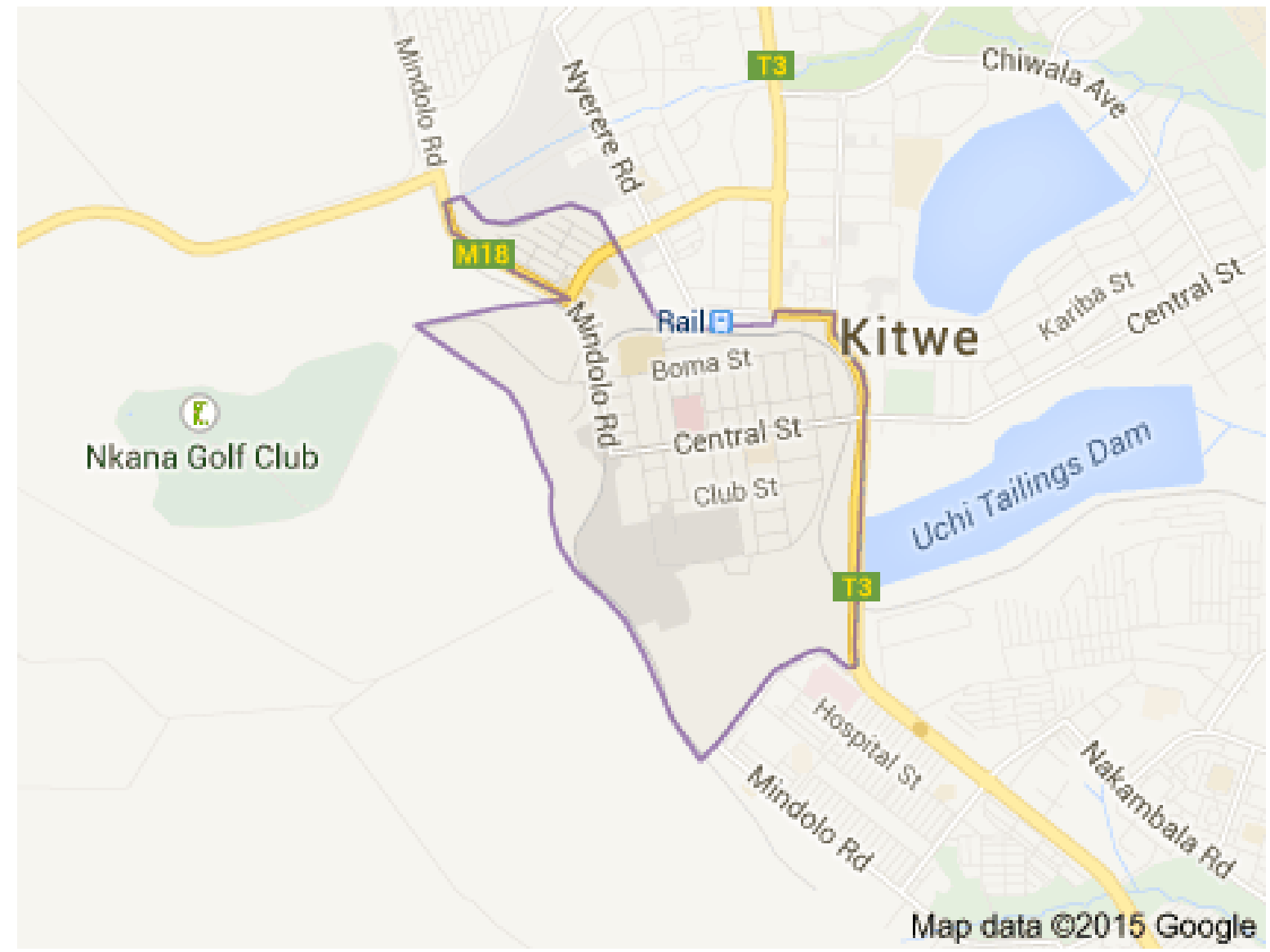

Figure 1. Map showed the location of Kitwe on the Copperbelt. Source: Google Maps Data (2015).

Kitwe is located at $12^{\circ} 49^{\prime}$ South and $28^{\circ} 12^{\prime}$ East. The town was founded in 1936 and attained a city status in 1966. Kitwe is the second fastest growing district after Mpongwe with an annual growth rate of 3.2\% and has the largest population of 517,543 people (Central Statistical Office [CSO], 2012, p. 15). The district has a land area of $777 \mathrm{~km}^{2}$ and this translates to a population density of $666.1 / \mathrm{km}^{2}$. It is the highest densely populated of all the 10 Copperbelt districts as illustrated in Table 1.

Kitwe has developed from an industrial and commercial area and later to an important agricultural area. The good central position of the city in the Copperbelt area made it the most popular choice for industrial developers. 
The study focused on Kitwe as it is one of the most industrious and densely populated area on the Copperbelt. Three residential areas were selected under the classification of high, medium, and low cost housing units. These have an inverse correlation with population sizes. The sample areas were Nkana West, Chimwemwe, and Saint Anthony (St. Anthony), respectively. Other than this categorization, these areas are of different socio-economic statuses. St. Anthony is a squatter settlement with a population of low income levels, Chimwemwe is a city council residential area with a population of medium income levels, and Nkana West is a mine township with at least high income levels.

Table 1

Population Distribution of the Copperbelt Districts

\begin{tabular}{llll}
\hline District & Population & Area $\left(\mathrm{km}^{2}\right)$ & Population density $\left(\right.$ population $\left./ \mathrm{km}^{2}\right)$ \\
\hline Chililabombwe & 91,883 & 1,026 & 89.5 \\
Chingola & 216,626 & 1,678 & 129.1 \\
Kalulushi & 100,381 & 725 & 138.5 \\
Kitwe & 517,543 & 777 & 666.1 \\
Luanshya & 156,059 & 811 & 192.4 \\
Lufwanyama & 78,503 & 9,849 & 8.0 \\
Masaiti & 103,857 & 5,383 & 19.3 \\
Mpongwe & 93,380 & 8,339 & 11.2 \\
Mufulira & 162,889 & 1,637 & 99.5 \\
Ndola & 451,246 & 1,103 & 409.1 \\
\hline
\end{tabular}

Note. Source: Central Statistical Office (CSO) (2012, p. 17).

\section{Statement of the Problem}

There are gaps in urban health hazards in Zambia as not much research has been done in relation to the subject. However, vigorous research has been done on health, health safety, and risks. The people could have knowledge on the urban health hazards but perceive them differently. Therefore, this study wanted to establish the knowledge and perceptions of the people of Kitwe on urban health hazards.

\section{Methodology}

An interview schedule was used to obtain information from the households that were purposely chosen. These interviews drew information on the respondents' background, knowledge, and perceptions on urban health hazards.

\section{Sample Areas and Sample Size}

Three areas were selected according to socio-economic and designations of squatter, council, and mine townships. The sample areas were St. Anthony, Chimwemwe, and Nkana West, and the sample sizes were 19, 17, and 17 households, respectively.

\section{Results and Discussion}

\section{Sample Characteristics}

The sample comprised of 22 males and 31 females as shown in Table 2. 
Table 2 shows that $41.5 \%$ of the respondents were males and $58.5 \%$ of them were females. Nkana West had the biggest number of females who indicated that the males were at work.

Table 2

Respondents by Gender

\begin{tabular}{|c|c|c|c|c|c|c|c|c|}
\hline \multirow{2}{*}{ Gender } & \multicolumn{2}{|c|}{ Whole sample } & \multicolumn{2}{|c|}{ St. Anthony } & \multicolumn{2}{|c|}{ Chimwemwe } & \multicolumn{2}{|c|}{ Nkana West } \\
\hline & Frequency & Percent $(\%)$ & Frequency & Percent (\%) & Frequency & Percent (\%) & Frequency & Percent $(\%)$ \\
\hline Male & 22 & 41.5 & 9 & 17.0 & 8 & 15.1 & 5 & 9.4 \\
\hline Female & 31 & 58.5 & 10 & 18.8 & 9 & 17.0 & 12 & 22.7 \\
\hline Total & 53 & 100.0 & 19 & 35.8 & 17 & 32.1 & 17 & 32.1 \\
\hline
\end{tabular}

Note. Source: Field Data (2014).

The average level of education was secondary but $29.4 \%$ of the respondents from Nkana West $(15.1 \%)$ and the respondents from Chimwemwe (11.3\%) were well above the average. This meant that they were well-educated to the level where they were able to make rational decisions about their wellbeing. Those in St. Anthony have only attained up to secondary education level (see Table 3).

Table 3

Respondents' Education Levels

\begin{tabular}{|c|c|c|c|c|c|c|c|c|}
\hline \multirow{2}{*}{ Education level } & \multicolumn{2}{|c|}{ Whole sample } & \multicolumn{2}{|c|}{ St. Anthony } & \multicolumn{2}{|c|}{ Chimwemwe } & \multicolumn{2}{|c|}{ Nkana West } \\
\hline & Frequency & Percent (\%) & Frequency & Percent (\%) & Frequency & Percent (\%) & Frequency & Percent $(\%)$ \\
\hline None & 1 & 1.9 & 1 & 1.9 & 0 & 0 & 0 & 0 \\
\hline Primary & 12 & 22.6 & 6 & 11.3 & 4 & 7.6 & 2 & 3.8 \\
\hline Secondary & 26 & 49.1 & 12 & 22.6 & 7 & 13.2 & 7 & 13.2 \\
\hline College & 12 & 22.6 & 0 & 0 & 5 & 9.4 & 7 & 13.2 \\
\hline University & 2 & 3.8 & 0 & 0 & 1 & 1.9 & 1 & 1.9 \\
\hline Total & 53 & 100 & 19 & 35.8 & 17 & 31.1 & 17 & 31.1 \\
\hline
\end{tabular}

Note. Source: Field Data (2014).

\section{Knowledge About Urban Health Hazards}

The survey revealed that $98 \%$ of the respondents knew about the urban health hazards while $2 \%$ did not know of any. The hazards that were identified were:

(1) Sanitation: This was attributed to poor drainage system that left a lot of stagnant water, poor garbage disposal, and lack of/inadequate toilets;

(2) Unhygienic environmental conditions;

(3) Inadequate water supply;

(4) Noise, water, and air pollution;

(5) Improper housing units;

(6) Too many alcoholic outlets and night clubs;

(7) Accidents;

(8) Overcrowding;

(9) Lack of recreation facilities;

(10) Peer pressure; 
(11) Use of contraceptives;

(12) Inadequate or lack of formal education;

(13) Poisonous plants.

The respondents were asked to mention multiple health hazards they knew, from the information in Table 4, $39.6 \%$ of the responses indicated that unhygienic environments were a great hazard to people's health; while $35.9 \%$ of the responses showed that air pollution was equally a big concern. Promiscuous behavior, inadequate food supply, and poor garbage disposal were also ranked high in their contribution toward the health risks of the people of Kitwe. Out of all the known health hazards, the respondents' prioritized them as follows (see Table 5):

Table 4

Respondents' Knowledge of Urban Health Hazards

\begin{tabular}{lll}
\hline Urban health hazard & Frequency of the responses & Percentage (\%) \\
\hline Poor drainage & 8 & 15.1 \\
Inadequate food & 16 & 30.2 \\
Unhygienic environments & 21 & 35.9 \\
Poor garbage disposal & 15 & 28.3 \\
Unemployment & 7 & 13.2 \\
Water pollution & 8 & 15.1 \\
Noise pollution & 3 & 5.7 \\
Improper housing units & 4 & 7.5 \\
Too many alcoholic outlets & 5 & 9.4 \\
Poor sanitation & 9 & 17 \\
Air pollution & 21 & 39.6 \\
Promiscuous behavior & 17 & 32.1 \\
Inadequate water supply & 5 & 9.4 \\
Other hazards & 21 & 39.6 \\
\hline
\end{tabular}

Note. Source: Field Data (2014).

Table 5

Respondents' Order of the Most Common Urban Health Hazards

\begin{tabular}{llll}
\hline S/No. & Urban health hazard & Frequency & Percentage (\%) \\
\hline 1 & Air pollution & 15 & 28.3 \\
2 & Promiscuous behavior & 8 & 15.1 \\
3 & Poor sanitation & 7 & 13.2 \\
4 & Unemployment & 4 & 7.6 \\
5 & Poor drainage & 4 & 7.6 \\
6 & Water pollution & 3 & 5.7 \\
7 & Too many mosquitoes & 3 & 5.7 \\
8 & Inadequate food supply & 2 & 3.8 \\
9 & Poor waste disposal & 2 & 3.8 \\
10 & Too many alcoholic outlets & 2 & 3.8 \\
11 & All of the above & 2 & 3.8 \\
12 & I do not know & 1 & 1.9 \\
\hline
\end{tabular}

Note. Source: Field Data (2014). 


\section{Air Pollution}

According to the Environmental Council of Zambia (ECZ, 2005), it defines air pollution as the presence of any chemical, physical, and biological agent that modifies the natural air condition of the atmosphere. The most widespread types of pollutants are ozone (smog) and particle (soot) that are accompanied by other serious pollutants such as carbon monoxide, lead, nitrogen dioxide, sulphur dioxide, and toxins like mercury, arsenic, benzene, and formaldehyde. Air pollution is detrimental to life. These pollutants have the capacity of making the population sick from various diseases such as neural disorders (lead and benzene) and respiratory disorders (carbon dioxide and sulphur dioxide) (Canadian Centre for Occupational Health and Safety [CCOHS], 2013; Lusakatimes.com, 2012).

In 1922 and 1950, Poga-Rica suffered air pollution that was caused by an accident from an oil refinery plant. This accident killed and sickened workers and residents. In 1950, there was London smog that left 4,700 people dead. The smog was caused by industrial smoke and sulphur dioxide (Burton, Kates, \& White, 1978). Air pollution can also take the form of thermal pollution due to atmospheric interferences by the aviation industry and volcanic eruptions in areas where such happen. The frequency of planes is ever increasing worldwide. Zambia may seem not to have her own airline, but has quite a number of international airlines that use her air space and air ports. Therefore, this also contributes to air pollution.

Zambia is basically a copper mining country and Kitwe houses one of the underground mines where copper is mined and processed. During the processing of this copper, sulphur monoxide is emitted and this transforms into sulphur dioxide after oxidation. This gas has a number of effects on the population and the environment. The pungent smell causes respiratory irritation that causes repeated coughing, skin and eyes irritation, nasal and throat mucus membrane corrosion. The effect on the environment is intense during the rainy season as acid rain is produced. This not only kills the plants but also pollutes the ground. Nkana West which is close to the Nkana mine suffers these effects. That is why $82.4 \%$ of the respondents in this residential area ranked air pollution as a major health hazard whilst the respondents of Chimwemwe and St. Anthony ranked promiscuous behavior (17.7\%) and sanitation (29.4\%), respectively, as major health hazards. Only 5.9\% of the respondents in Chimwemwe and St. Anthony knew that air pollution was detrimental to their health. This shows that despite the two residential areas being closer to Mindolo shaft, the residents did not experience air pollution as much as those in Nkana West. Figure 2 shows smoke being emitted into the atmosphere in Kitwe. One dimension of pollution that has been neglected is indoor air pollution. This affects the quality of the air indoors and this is by far the most deadly risk globally (Wikipedia, retrieved March 18, 2015). A major source of indoor pollution in developing countries like Zambia is the burning of biomass (wood, charcoal, and crop residue) for cooking and heating. This was common in St. Anthony and parts of Chimwemwe townships. Nkana West residents supplement their electric source of energy with charcoal.

\section{Promiscuous Behavior}

Fifteen point one percent (15.1\%) of the whole sample revealed that promiscuous behavior was a health hazard. They attributed this to the numerous alcoholic outlets and unemployment which encouraged illicit relationships. These made the residents more vulnerable to sexually transmitted infections such as Human Immunodeficiency Virus (HIV) and Acquired Immune Deficiency Syndrome (AIDS). Twenty four percent (24\%) of the respondents in Chimwemwe knew of the promiscuous behavior as a hazard and only $18 \%$ perceived it as harmful to human health. In St. Anthony, 58\% of the respondents had knowledge about 
promiscuous behavior and only $21 \%$ perceived it as a health hazard. In Nkana West, $18 \%$ of the respondents had knowledge about promiscuous behavior and only $6 \%$ of them perceived it as a health hazard. The results indicate the inverse relationship between the socio-economic statuses of the residential areas and the occurrence of promiscuous behavior.

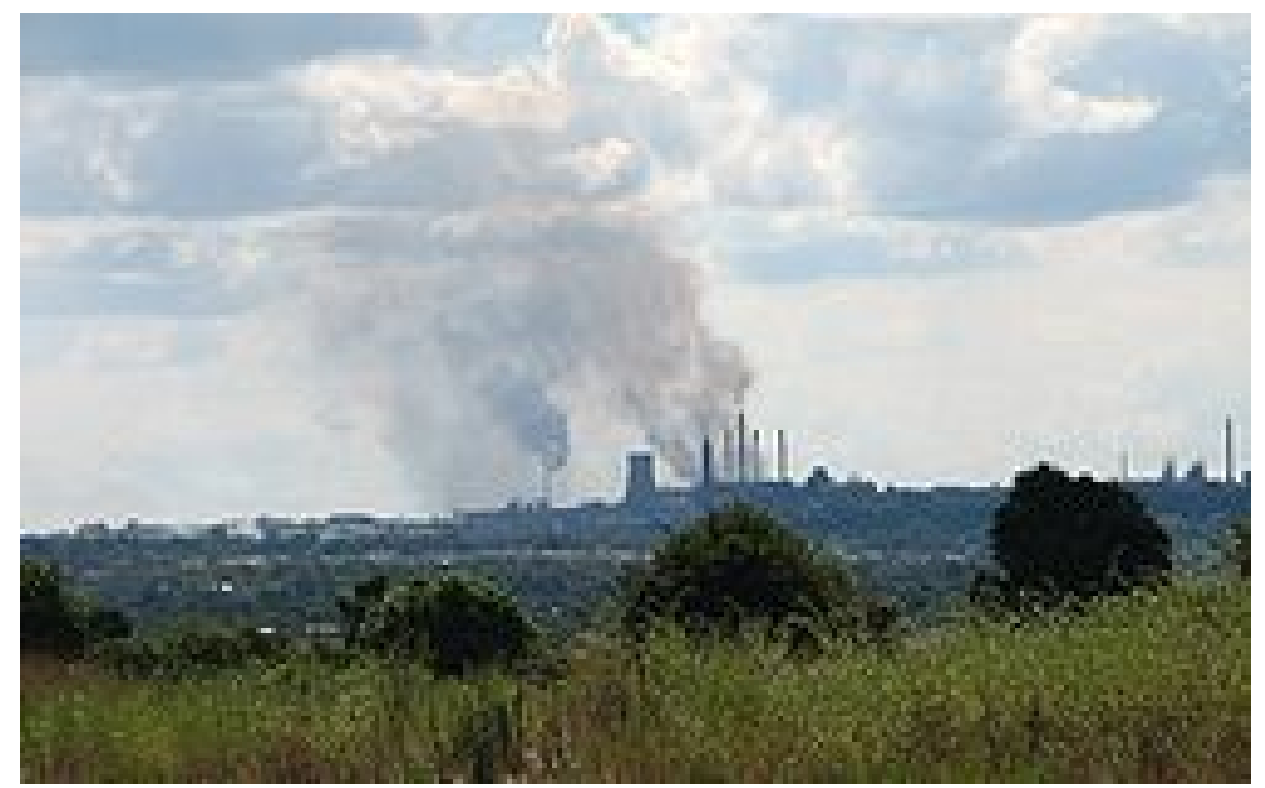

Figure 2. Air pollution in Kitwe. Source: Google Maps Data (2015).

\section{Poor Sanitation}

Sanitation is a broader aspect as it encompasses a lot of things such as waste, drainage, toilets, nature of housing units, ventilation, and water sources, to mention just some.

\section{Waste Disposal}

There are two types of waste the study brought to the fore and these are: the faecal waste and solid waste. The faecal waste occurs as a result of old pipes and manholes bursting and overflowing respectively. This scenario was common in Chimwemwe and Nkana West. St. Anthony had a different problem and this was that of inadequate pit latrines. Households shared these facilities. The areas where the some houses have been constructed are so small such that they cannot accommodate even a small pit latrine. To some extent, other people defecate in plastics or opaque beer containers which they throw on garbage heaps. This situation is a volatile health hazard. Solid waste disposal has become an environmental issue as local councils and Environmental Council of Zambia (ECZ) have discouraged the burning of refuse in compounds by households.

Through the Public Private Partnerships (PPPs), solid waste disposal is management by a lot of stake holders who have come on board. The refuse was collected after a waste management fee had been paid to the company. The scenario was same country wide. However, in Kitwe, not every resident had the capacity to pay for the service. Some of them resorted to indiscriminate disposal of garbage thereby enhancing the sanitation problem (see Figure 3).

\section{Poor Drainage}

Poor drainage was caused by blockage of the drainage canals that had become solid waste dump sites. Some areas were faced with water logging as illustrated in Figure 4. 


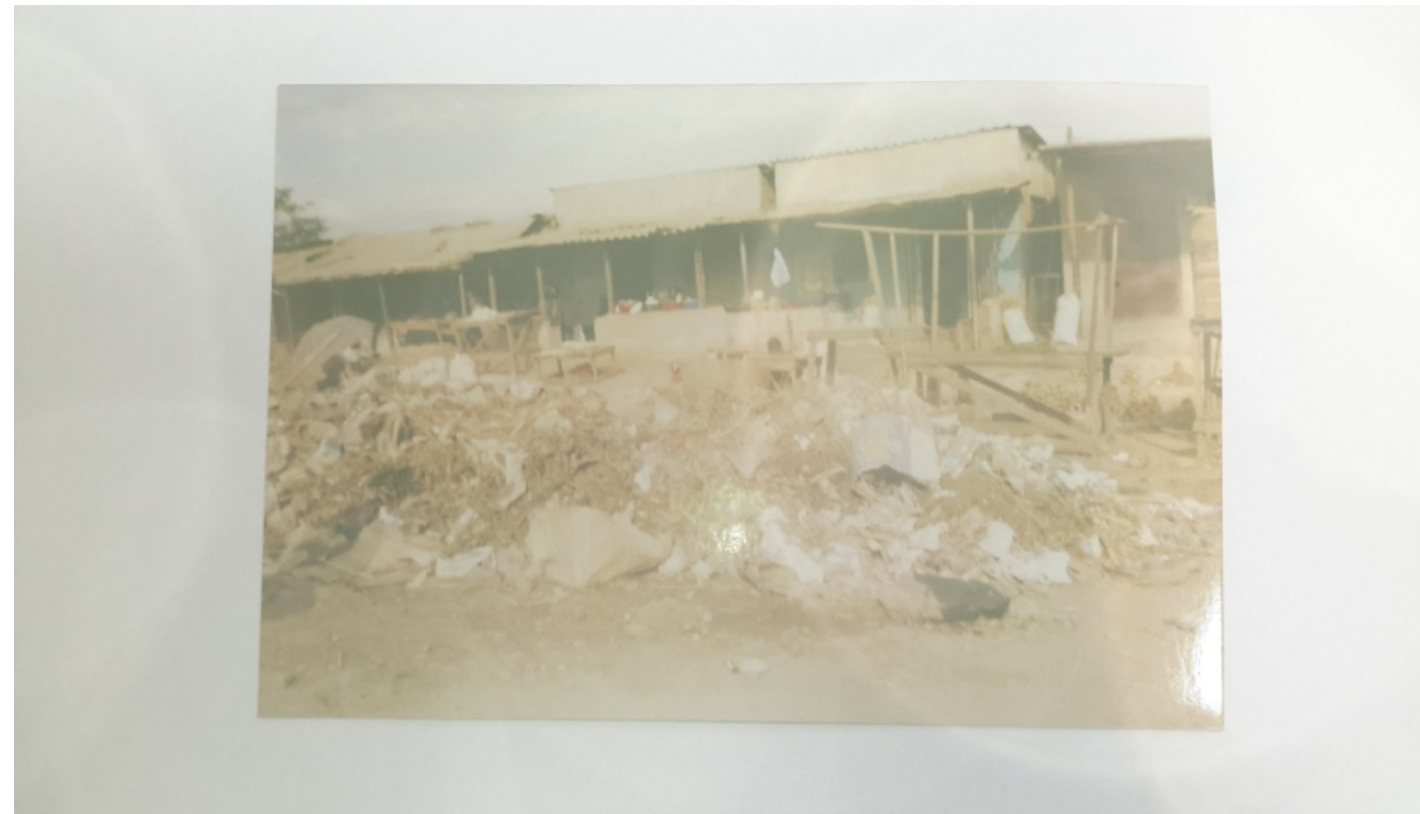

Figure 3. Solid waste disposal. Source: Field Data (2014).

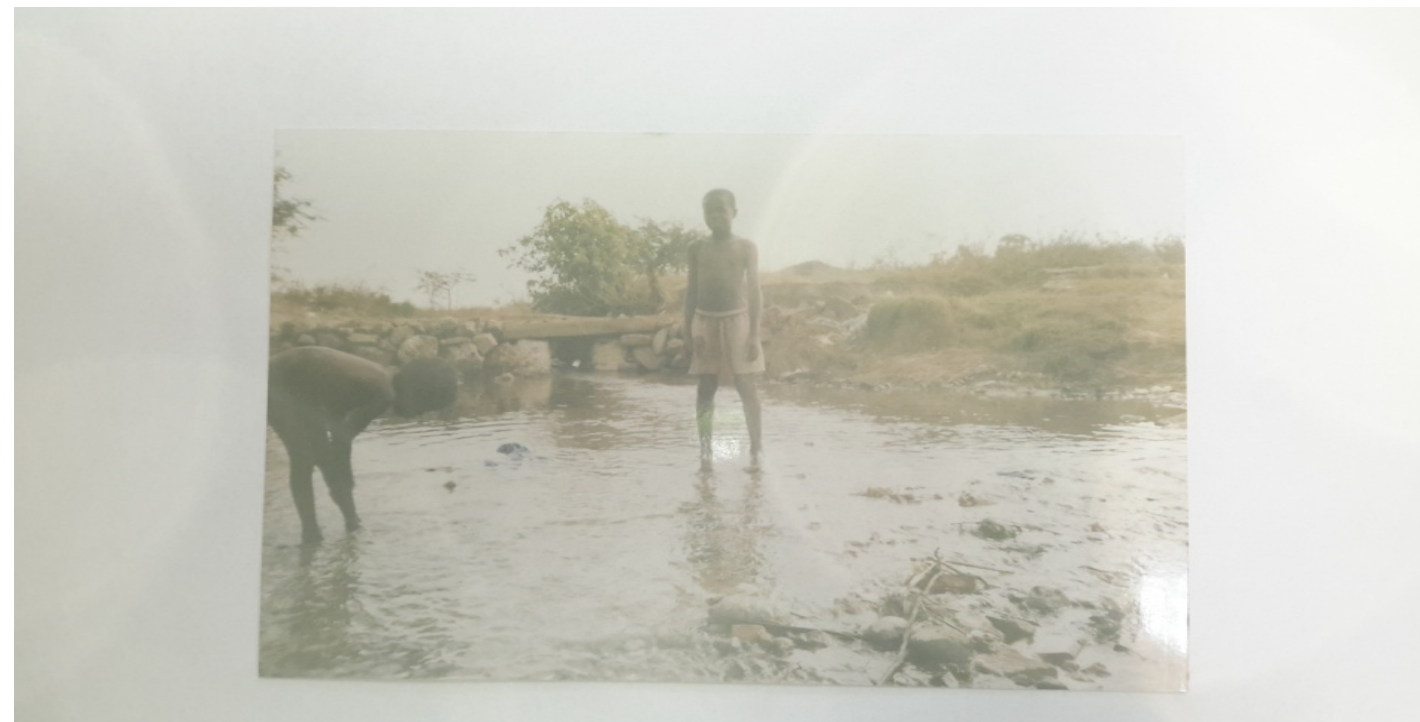

Figure 4. Water logged area in Kitwe. Source: Field Data (2014).

\section{Types of Houses}

This was a concern in St. Anthony and some part of Chimwemwe. The houses were small with a few windows for the households that could afford the glass panes and small holes in the walls to let air in cases where the households could not afford to fix windows. St. Anthony by virtue of being a squatter compound faced challenges in housing. In Chimwemwe, a designated council residential area had either small adjacent apartment to the main house or on the peripheral areas of the yard that were poorly ventilated. The types of houses in these two areas had the potential of increasing the chances of spreading communicable diseases such as malaria (vector borne), influenza/common cold (viral), and tuberculosis (bacteria), due to poor house ventilation and overcrowding. 


\section{Water Sources}

The residents use different sources of water. Most households in Nkana West have piped water supply within their premises, while some in St. Anthony use communal taps and shallow wells. In Chimwemwe, due to clogging of the some pipes, water is a challenge to residents in that they have to depend on the few that are running (see Figure 5).

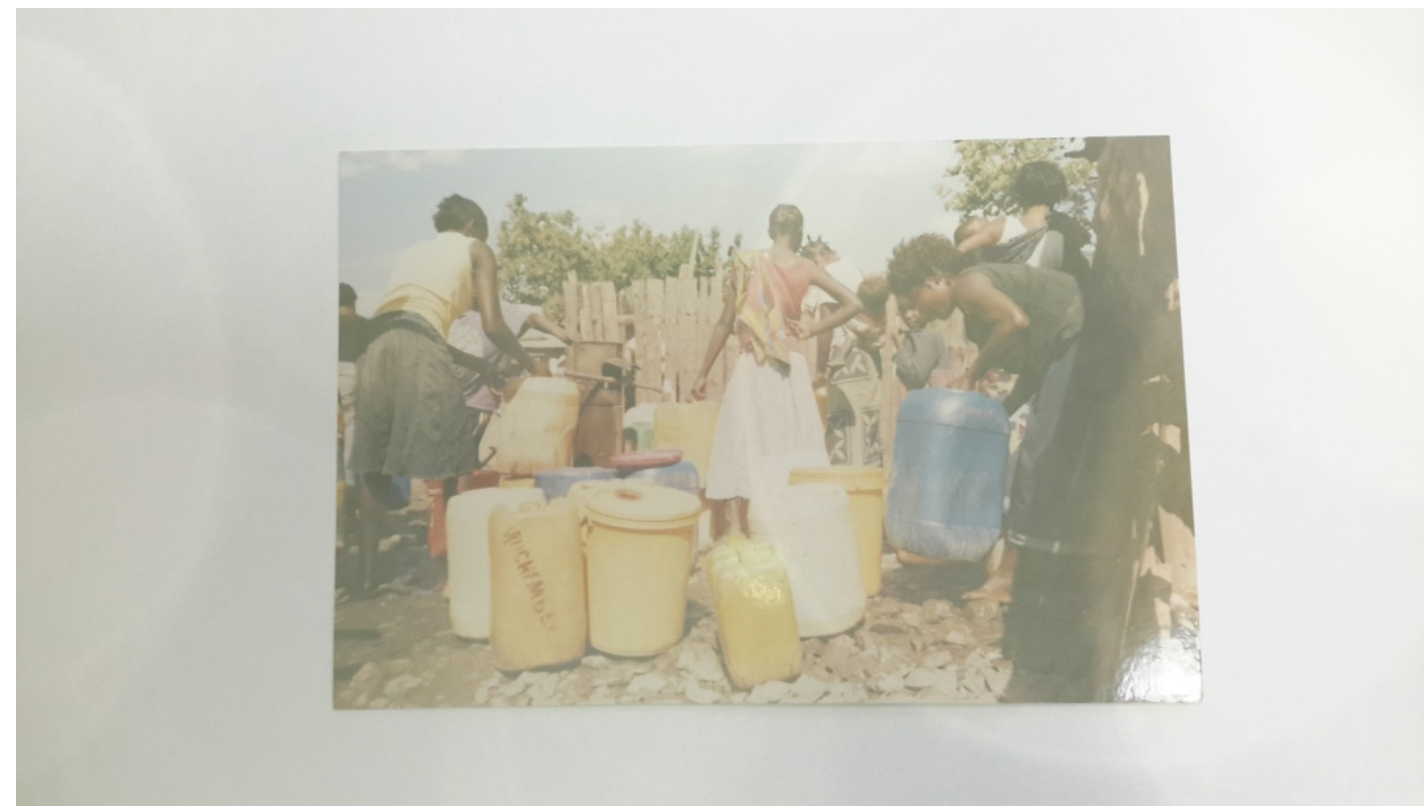

Figure 5. Women drawing water from a communal water source. Source: Field Data (2014).

\section{Perceptions on the Urban Health Hazards}

The respondents perceived the urban health hazards as a result of negligence of the local authority's failure to put things in perspective in order to better their (respondents) lives. In Chimwemwe, the respondents blamed the city council, the Nkana Water and Sewerage Company (NWSC), and the government at large for the deterioration of the environmental conditions. However, they acknowledged responsibility over enhancing the illegal waste disposal in undesignated sites. Meanwhile, the respondents from St. Anthony and Nkana West blamed the mine authorities for air pollution.

\section{Air Pollution}

Forty-two percent (42\%) of the respondents attributed air pollution to the mine emissions, while $36 \%$ of them attributed the health hazards with air pollution from other sources such as combustion from the automobiles, burning of domestic refuse, domestic cooking fuels (charcoal and wood), and solid waste dumps within the residential areas.

As many respondents thought that the mines were the chief pollutants, the increasing numbers of automobiles and factories were equally contributing highly to pollution through water and air contamination, and noise. The increase of automobiles is a recent phenomenon in Kitwe that after 1992 was almost dying due to the privatization and liquidation of the mines and underperforming parastatal companies respectively. The enabling investment climate that came with the change of political leadership in 2001-the "new deal government", encouraged local, foreign, private, and public investment in Kitwe and the country as a whole. 
Another dimension to increased investment is the urban sprawl which has come with its own challenges.

According to Palichino and Mollet (2003), they consider that transport is one of the major contributors to pollutants such as carbon monoxide, nitrogen oxide, sulphur dioxide, lead, and particulate matter. The WHO estimated that about "700,000 could be prevented in developing countries if pollutants were reduced to safer levels" (Palichino \& Mollet, 2003, p. 8). A survey that was done in Benin to determine the motorbike drivers' levels of carcinogenic pollution revealed that the pollution was high at cross roads and roundabouts. The main pollutants were benzene and ethyl benzene. These chemicals impact on the health of the people and cause short- and long-term effects such as tremors, drowsiness, dizziness, skin and eye irritation; and aneamia, infertility, and leukemia (cancer of the blood), respectively (American Cancer Society, 2013).

\section{Promiscuous Behavior}

Lack of recreation facilities, unemployment, lack of/inadequate food supplies were seen as reasons for illicit relationships and activities. These illicit relationships were done in order to raise money for food. The respondents blamed the city council for selling recreation parcels of land for residential plots and this resulted in inadequate or lack of recreation, especially the youths.

Beer drinking was identified as one of the sources of promiscuous behavior in St. Anthony and Chimwemwe. In these areas, there were also numerous bars and night clubs.

\section{Poor Sanitation}

The city council and NWSC are perceived to perpetuate the health hazards that the respondents identified and had knowledge about. The local council was expected to ensure and uphold sanitation levels by minimizing overcrowding in the compounds. This could be done by monitoring developmental projects in these areas to see if the residents were complying with the norms of construction.

\section{Solid Waste Disposal}

The garbage was disposed off indiscriminately. This caused it to be a health hazard. Flies and rodents found a niche in these heaps of garbage. These vectors were the carriers of bacteria and fleas that caused diarrhoeal diseases and plague, respectively. Combustion of the garbage produced odour that polluted the micro-atmosphere and also produced heat that contributed to thermal heating. Therefore, the houses that were located close to these places were heavily polluted. These areas of garbage were also breeding grounds for mosquitoes. Despite the Konkola Copper Mines carrying out the malaria control and eradication campaigns, the district was still prone to the disease (malaria).

\section{Drainage}

The Presidential Housing Initiative (PHI) of 1996 saw a lot of people in Zambia being empowered with houses as sitting tenants. The houses that belonged to the state and parastatals were sold off. This created the need for more housing units especially in the urban towns. Hunger for plots grew more and more, and infrastructural development more especially houses was on an upswing. Some houses have been constructed on road reserves and drainage areas that made it difficult for the Road Development Agency (RDA) to undertake road construction without issues of compensation. This had generally contributed to poor drainage.

In St. Anthony, there was a small nearby stream where domestic shores such as laundry are done and some children swim in this very stream. At the same time, people disposed off their garbage (plastic paper and bottles) that worsened the sanitary condition of the stream. 


\section{Conclusions}

The study revealed that the socio-economic variations of the sample areas had influence on the knowledge and perceptions on urban health hazards. There was need to scale up or introduce health education campaigns on a number of health hazards such as need for sexual behavioral change and positive attitudes toward sanitation and pollution. In order to avoid water logging problem that is caused by the construction of houses on drainage sites and in dambos, the government through the Kitwe City Council (KCC) should monitor the allocation of plots and the construction of houses.

The PPPs should be encouraged and enhanced in order to improve sanitation and reduce pollution.

\section{References}

Agency for Toxic Substances and Disease Registry (ATSDR). (1998). Public health statement for sulfur dioxide. Retrieved from http://www.atsdr.cdc.gov

Akhtar, R. (1988). Perceptions of urban health hazards: Examples from Lusaka. International Journal of Environmental Studies, 31(2-3), 167-172.

American Cancer Society. (2013). Carcinogenic effects of air pollution. Retrieved from http://www.cancer.org

Burton, I., Kates, R. W., \& White, G. W. (1978). The environment as hazard. Retrieved from http://www.amazon.com

Canadian Centre for Occupational Health and Safety (CCOHS). (2013). Effects of sulphur oxide on health. Retrieved from http://www.ccohs.ca/oshanswers/ chemicals/chemical profiles/ sulfurdi.Html

Central Statistical Office (CSO). (2012). 2010 census of population and housing: Population summary report. Lusaka: CSO.

Chanda, R. (2004). Trade in health services. Retrieved from http://www.who.int/trade/resource/THS/en/

Environmental Council of Zambia (ECZ). (2005). State of environment reporting in Zambia: Proceedings of a training workshop on indicator development. Lusaka: ECZ.

Government of the Republic of Zambia and United Nations Development Programme (GRZ \& UNDP). (2013). Millennium development goals-Progress report: Zambia 2013. GRZ and UNDP, Lusaka.

Lusakatimes.com. (2012). The choking fumes in Kitwe. Retrieved from http://www.lusakatimes.com

Palichino, M., \& Mollet, P. (2003). Better urban mobility in developing countries. Brussels: International Association of Public Transport. 